\title{
Experimental research of the colloidal systems with nanoparticles influence on filtration characteristics of hydraulic fractures
}

\author{
V.V. Sergeev ${ }^{1 *}$ (D) R.R. Sharapov², A.Y. Kudymov³, Y.V.Zeigman4, V.S. Mukhametshin ${ }^{5}$ \\ ${ }^{1}$ VI-ENERGY LLC, Skolkovo Foundation, Moscow, Russia; \\ ${ }^{2}$ RN-BashNIPIneft LLC, Ufa, Bashkortostan Republic, Russia; \\ ${ }^{3}$ Tyumen Oil Scientific Center LLC, Tyumen, Tyumen Region, Russia; \\ ${ }^{4}$ Ufa State Petroleum Technological University, Ufa, Bashkortostan Republic, Russia; \\ ${ }^{5}$ Oktyabrsky branch of Ufa State Petroleum Technological University, Oktyabrsky, Bashkortostan Republic, Russia \\ * Corresponding author: e-mail: sergeev@vi-energy.ru \\ (c) Authors, 2020
}

\begin{abstract}
Colloidal systems in form of emulsions or suspensions are widely used in various of industries including oil-gas fields development industry. Invert emulsions and suspensions are actively applied in fields development, including enhanced oil recovery, intensification of oil production, drilling and wells workover. Results of laboratory tests for studying physical properties of heterogeneous systems as an emulsion system with nanoparticles and emulsion-suspension system with nanoparticles are presented in this paper. Having unique physical and chemical properties these systems can be effectively applied in upstream of oil and gas as a water-limiting agent or blocking pack with reversible effect. In framework of this research, laboratory tests for evaluation of the influence of the new systems on filtration characteristics of hydraulic fractures are carried out. Laboratory tests are planned in accordance with requirements of international standards and conducted under the closest conditions to subsurface thermal and pressure conditions of formations $\mathrm{S}_{\text {Tyr }}$ Abdylovskoe, $\mathrm{S}_{\text {BASh }}$ Yugomashevskoe and YuS-2 and YuS-4 of Tortasinskoe oil-gas fields. Based on the results, permeability and conductivity indexes of the models of hydraulic fractures before and after filtration of the new types of colloidal systems are calculated. In order to evaluate an efficiency of the new systems and to study a possibility to regulate its blocking properties an analysis of the impact made by a type and a quantity of nanosized solids on to the blocking properties is carried out. An optimal concentration of nanoparticles in the compositions for a range of formation conditions of particular carbonate and sandstone subsurface reservoirs of oil-gas fields of Russian Federation are represented in this paper.
\end{abstract}

KEYWORDS: nanoparticles; silicon dioxide; emulsion system; emulsion-suspension system; hydraulic fracture.

FOR CITATION: Sergeev V.V., Sharapov R.R., Kudymov A.Y., Zeigman Y.V., Mukhametshin V.S. Experimental research of the colloidal systems with nanoparticles influence on filtration characteristics of hydraulic fractures. Nanotechnologies in Construction. 2020, Vol. 12, no. 2, pp. 100-107. DOI: 10.15828/2075-8545-2020-12-2-100-107.

\section{INTRODUCTION}

$\mathrm{C}$ urrent worldwide level of development of experimental methods for simulation of liquids filtration in porous media provides opportunity to study filtration processes with a high degree of similarity to natural conditions of subsurface formations [1-9]. Continuity of improvement and development of this direction of experimental researches determined by progress of governmental standards in the area of environmental engineering and human health safety, as well as supported by the internal requirements of industry enterprises to the quality of the laboratory test results and growth of the demand of oil and gas enterprises for new water-blocking agents and technologies of its application in hydraulically fractured wells [10-14]. For example, to date, in Russian Federation most of the oil and gas companies established an internalregulative requirements to the list and methods of laboratory tests for new chemical products. In the framework of these requirements, a new chemical products for use in subsurface formations must be tested on the subject of compatibility with technological liquids, formation fluids, as well as evaluated from the point of view of impact on to the filtration-capacitance characteristics of rocks in the closest conditions to the conditions of subsurface formation. 
Research results represented in this paper obtained in framework of leading the research-industrial pilot projects for implementation of water-limiting agent in the form of emulsion system with nanoparticles [15-18], and blocking agent in the form of emulsion-suspension system with nanoparticles [19] on the several oil-gas fields of Russian Federation. Geological and physical characteristics of the oil-gas bearing formations considered oil-gas fields are described by significant differences in formation temperatures 22 to $98^{\circ} \mathrm{C}$ and formation pressures 8 to $39 \mathrm{MPa}$. With the task of simulation of the hydraulic fractures under formation conditions the proppant grade CarboProp 16/20 for the formations $\mathrm{S}_{\mathrm{Tyr}}$ Abdylovskoe, $\mathrm{S}_{\mathrm{BASh}}$ Yugomashevskoe and CarboProp 20/40 for the formations YuS-2 and YuS-4 of Tortasinskoe oil-gas fields have been used.

\section{METHODS AND PROCEDURES}

On the materials and technological liquids preparation stage to the laboratory tests the following colloidal systems have been prepared: emulsion system with nanoparticles (ESN) applied as a water-limiting agent in intensification of oil production and the enhanced oil recovery; emulsion-suspension system with nanoparticles (ESS) applied in drilling and wells workover. The data about the content of liquid and solid phases in the compositions is shown in table 1 .

Brief characteristics of subsurface formation conditions for Abdylovskoe, Yugomashevskoe and Tortasinskoe oil-gas fields is shown in the table 2 .

\section{Method for calculation of the density of proppant pack}

Calculation of the density of proppant pack is conducted in accordance with the Russian governmental standard GOST R 51761-2013 «Alumosilicate proppant. Technical requirements» [20]. Tests and calculations are conducted with taking into account the Russian governmental standard GOST 8.417-2002 «Interstate standard. State system for ensuring uniformity of measurements. Units of measure» [21].

Experiments for calculation of the density of proppant pack are carried out in room temperature. A $150 \mathrm{~cm}^{3}$ of test sample was poured into a funnel, the outlet of which is closed by a rubber locking ball. A calibrated cylinder was placed under the center of the outlet of the funnel. Moving the rubber ball to the left or right, the entire volume of proppants was released into the cylinder. The excess proppant in the calibrated cylinder was carefully removed with a glass plate along the cylinder edge without shaking and tamping. A calibrated cylinder with a sample and a glass plate was weighed, and the weight in grams was recorded.

The density of proppant pack $\rho_{\text {нсп }}$ is calculated by the following equation (1):

$$
\rho_{\text {нсп }}=\frac{m_{\text {o.r. }}-m_{\text {o.с. }}}{V},
$$

where $m_{\text {о.п. }}-$ total cylinder mass with sample and plate, g;

$m_{\text {o.c. }}$ - total dry cylinder mass with plate, $\mathrm{g}$;

$V$ - cylinder volume, $\mathrm{cm}^{3}$.

\section{Table 1}

Content of silicon dioxide nanoparticles and water in composition of laboratory samples

\begin{tabular}{|c|c|c|}
\hline Sample codename & Content of nanoparticles, vol. $\%$ & Content of well-killing fluid, vol. \% \\
\hline ESN-1 & 0,5 & 81,5 \\
\hline ESN-2 & 1,0 & 71 \\
\hline ESS-1 & 0,5 & 89,5 \\
\hline ESS-2 & 1,5 & 85,5 \\
\hline
\end{tabular}

Table 2

Brief characteristics of subsurface formation conditions for Abdylovskoe, Yugomashevskoe and Tortasinskoe oil-gas fields

\begin{tabular}{|c|c|c|c|c|c|}
\hline $\begin{array}{c}\text { Oil-gas field } \\
\text { name }\end{array}$ & Formation & Rock type & $\begin{array}{c}\text { Effective pres- } \\
\text { sure, MPa }\end{array}$ & Temperature, ${ }^{\circ} \mathbf{C}$ & $\begin{array}{c}\text { Proppant } \\
\text { fraction }\end{array}$ \\
\hline Abdylovskoe & $\mathrm{S}_{\mathrm{Tyr}}$ & Carbonates & 8.0 & 27 & $16 / 20$ \\
\hline Yugomashevskoe & $\mathrm{S}_{\mathrm{BASh}}$ & Carbonates & 8.0 & 22 & $16 / 20$ \\
\hline Tortasinskoe & YuS-2/YuS-4 & Sandstones & $35.5 / 39.5$ & $97.8 / 98$ & $20 / 40$ \\
\hline
\end{tabular}


The arithmetic mean of the results of two parallel tests was taken as the result of the experiment.

According to the experiment results, the pack density of CarboProp brand proppants of the 20/40 fraction was $1.52 \mathrm{~g} / \mathrm{cm}^{3}$, the $16 / 20$ fraction was $1.26 \mathrm{~g} / \mathrm{cm}^{3}$.

\section{Method for calculation of the residual conductivity of hydraulic facture model}

Hydraulic facture model conductivity experiments were conducted in accordance with the international standard ISO 13503-5:2006 [22].

Before the experiments, the Ohio core plates and a technical water solution ( $2 \%$ aqueous solution of potassium chloride) were prepared.

The plates were placed in a special cell, a void space between the cell walls and the core plates was filled with a two-component sealant. Next, the cell was vacuumed for an hour, then placed in a heating oven with a temperature of $75^{\circ} \mathrm{C}$ for 4 hours for vulcanization of the sealant. After extraction from the heating oven, excess of the sealant was removed from the core plates, leaving a thin layer at the ends of the core plates.

In order to prepare the technical water solution, a $2 \%$ aqueous solution of potassium chloride was vacuumed for 3 hours, then nitrogen was saturated for at least 1 hour. This procedure was performed at least 3 times.

After the preparatory work, the tests to determine the residual conductivity of the models of hydraulic fractures (proppant pack) were started in the order described below.

An Ohio core was placed in the cell for mesuring the conductivity of the proppant pack, CarboProp grade proppant of the appropriate fraction with the required concentration of proppant was poured between the plates.
The calculation of the amount of proppant was performed according to the equation (2):

$$
\mathrm{M}_{\Pi}=6,452 \cdot \mathrm{C}
$$

where $\mathrm{M}_{\Pi}-$ proppant mass, $\mathrm{g}$;

C - proppant load, $\mathrm{kg} / \mathrm{m}^{2}$.

A cell with proppant and core was placed in a press, strain gauges, fluid supply tubes and differential pressure sensors were connected. Then a heating and stabilization of the entire system to formation temperature was performed. A scheme of the model of hydraulic fracture (proppant pack) is shown in Fig. 1.

Next, the initial loading of the system to 6,9 MPa was performed, and the assembly was checked for leaks with a pumping pressure of 3,45 $\mathrm{MPa}$. After checking for leaks, the proppant pack was saturated with a solution of potassium chloride. After holding for 12 hours, the width, conductivity and permeability of the proppant pack were measured at different flow rates of the technical water solution.

The filtration characteristics of the proppant pack were determined for an hour (until the pressure drop was established). The conductivity of the proppant pack was measured at flow rates corresponding to a pressure drop of 0.01 to $0.03 \mathrm{kPa}$. Conductivity was calculated by the equation (3):

$$
k W_{\mathrm{y}}=5.554 \cdot \mu \cdot Q \cdot L / \Delta P
$$

where $k W_{\mathrm{y}}$ - proppant pack conductivity, $\mu \mathrm{m}^{2} \cdot \mathrm{cm}$; $\mu$ - test fluid viscosity at test temperature, cps;

$Q-$ rate, $\mathrm{cm}^{3} / \mathrm{min}$;

$\Delta P$ - pressure drop (differential pressure), $\mathrm{kPa}$; $L$ - length between ports, $\mathrm{cm}$.

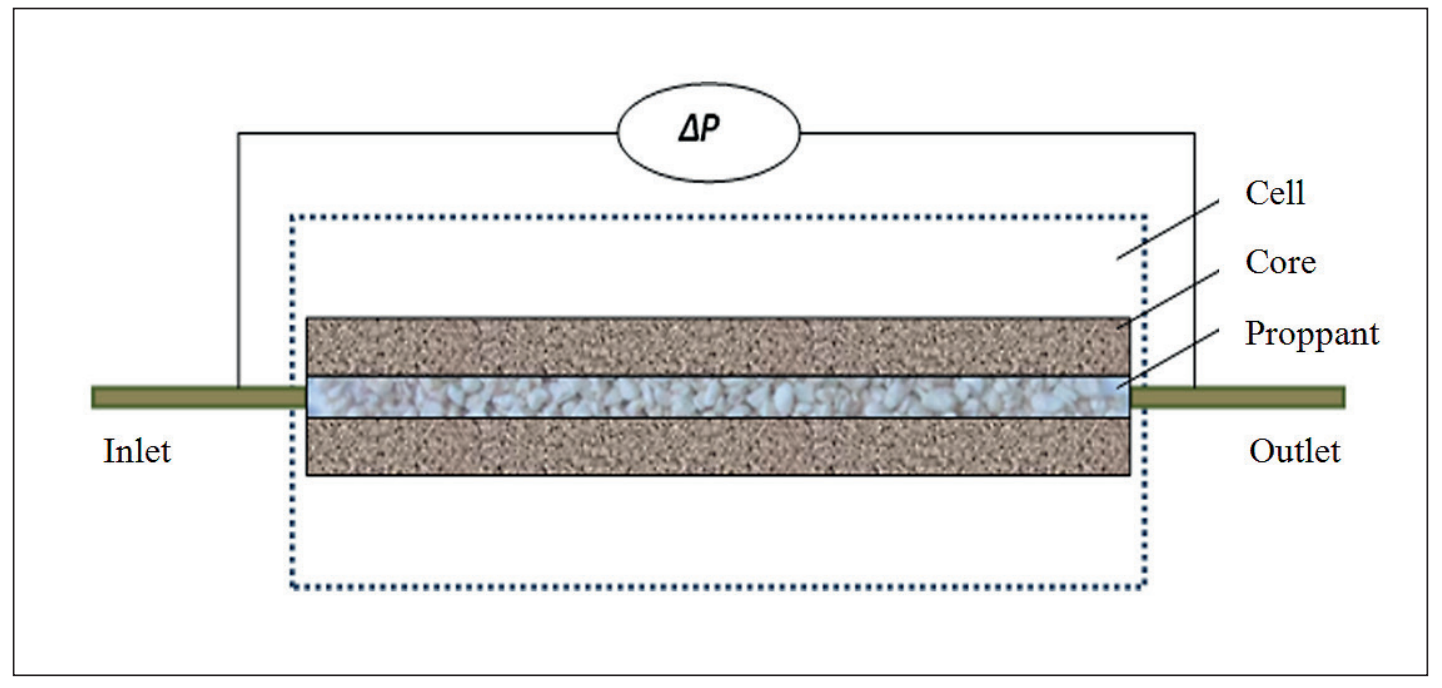

Fig. 1. Scheme of the model of hydraulic fracture (proppant pack) 
Permeability was calculated by the equation (4):

$$
k=100 \cdot \mu \cdot Q \cdot L \cdot[w \cdot(\Delta P) \cdot W \mathrm{y}]
$$

where $k$ - proppant pack permeability, $\mu \mathrm{m}^{2}$; $\mu$ - test fluid viscosity at test temperature, cps; $Q$ - rate, $\mathrm{cm}^{3} / \mathrm{min}$;

$\Delta P$ - pressure drop (differential pressure), $\mathrm{kPa}$;

$L-$ length between ports, $\mathrm{cm}$;

$W y$ - proppant pack width, $\mathrm{cm}$;

$w$ - cell width, $\mathrm{cm}$.

Next, the closing pressure was raised to an effective closing stress of $20 \mathrm{MPa}$, followed by exposure for 48 hours. The width, conductivity and permeability of the proppant pack were measured at different pumping rates of the technical water solution. The conductivity and permeability of the proppant pack were calculated using equations (3) and (4).

Next, the blocking composition was pumped in a volume of $200 \mathrm{~cm}^{3}$. Performed a technical pause for 2 hours. Then, the proppant pack was washed by filtering the technical water solution in a volume of $1000 \mathrm{~cm}^{3}$ at a flow rate of $5 \mathrm{~cm}^{3} / \mathrm{min}$ with a gradual increase in pressure at the inlet into proppant pack to the maximum pressure or water breakthrough with recording of dynamics.

The conductivity and permeability of the proppant pack were measured at various flow rates of the technical water solution. The filtration characteristics of the proppant pack were determined within an hour (until the pressure drop was established). The conductivity and permeability of the proppant pack were calculated using equations (3) and (4).

After measuring the conductivity and permeability of the proppant pack, the system was converted to atmospheric conditions, the cells were disassembled and cleaned.

Based on the measured conductivity and permeability before and after filtration of the blocking agent, the coefficients of restoration of the conductivity and permeability of the proppant pack were calculated using equations (5) and (6):

$$
\begin{aligned}
& K \mathrm{~B}_{k W y}=k W_{\mathrm{y} 2} / k W_{\mathrm{y} 1}, \\
& K_{\mathrm{B}_{k}}=k_{2} / k_{1},
\end{aligned}
$$

where $K \mathrm{~B}_{k W y}-$ coefficient of restoration of the conductivity, \%;

$K_{\mathrm{B}_{k}}-$ coefficient of restoration of the permeability, \%;

$k W_{\mathrm{y} l}$ - conductivity of the proppant pack before filtration of blocking agent, $\mu \mathrm{m}^{2} \cdot \mathrm{cm}$;

$k W_{\mathrm{y} 2}$ - conductivity of the proppant pack after filtration of blocking agent,

$\mu \mathrm{m}^{2} \cdot \mathrm{cm}$;

$k_{1}$ - permeability of the proppant pack before filtration of blocking agent, $\mu \mathrm{m}^{2}$; $k_{2}$ - permeability of the proppant pack after filtration of blocking agent, $\mu \mathrm{m}^{2}$.

Filtration experiments (proppant pack flooding) were performed on the PIK-API-RP-61 software and measuring complex designed to measure the following filtration characteristics of proppant pack in required thermal and pressure conditions:

- Long-term conductivity measurement;

- Residual conductivity measurement;

- Residual permeability measurement;

- Tests of blocking compounds and destructors under formation conditions;

- Crush resistance.

The measuring complex allows testing at a closing pressure of up to 100 tons, a maximum pumping pressure of $10 \mathrm{MPa}$ and a temperature of $150^{\circ} \mathrm{C}$.

\section{RESULTS AND OBSERVATIONS}

In order to study the water-limiting properties of the ESN used in the intensification of oil production and enhanced oil recovery, two experiments were conducted to determine the residual conductivity of hydraulic fracture models of Yugomashevskoe and Abdulovskoe oilgas fields. In these experiments, the pore pressure was 3.45 $\mathrm{MPa}$. The experimental conditions and the concentration of nanoparticles in the ESN-1 and ESN-2 systems are shown in Tables 1 and 2. Photographs of disassembled hydraulic fracture models after tests are presented in Fig. 2.

The results of experiments to study the water-limiting agent ESN influence on the filtration characteristics of fracturing models of Abdylovskoe and Yugomashevskoe oil-gas fields are shown in table 3 and Fig. 3.

According to the results of filtration experiments, it was determined that ESN systems significantly limit filtration of water in highly permeable hydraulic fracture models fixed with CarboProp proppant fraction 16/20 (Fig. 3). The reduction in conductivity and permeability of hydraulic fracture models is as following: for ESN-1 23 times; for ESN-2 - 18 times.

In order to study the blocking properties of the ESS used in the drilling and well workover, two experiments were conducted to determine the residual conductivity of hydraulic fracture models of Tortasinskoe oil-gas field. In these experiments, the pore pressure was $3.45 \mathrm{MPa}$. The experimental conditions and the concentration of nanoparticles in the ESS-1 and ESS-2 systems are shown in Tables 1 and 2. Photographs of disassembled hydraulic fracture models after tests are presented in Fig. 4.

The results of experiments to study the influence of the blocking agent ESS on the filtration characteristics of fracturing models of Tortasinskoe oil-gas field are shown in table 4 and Fig. 5. 


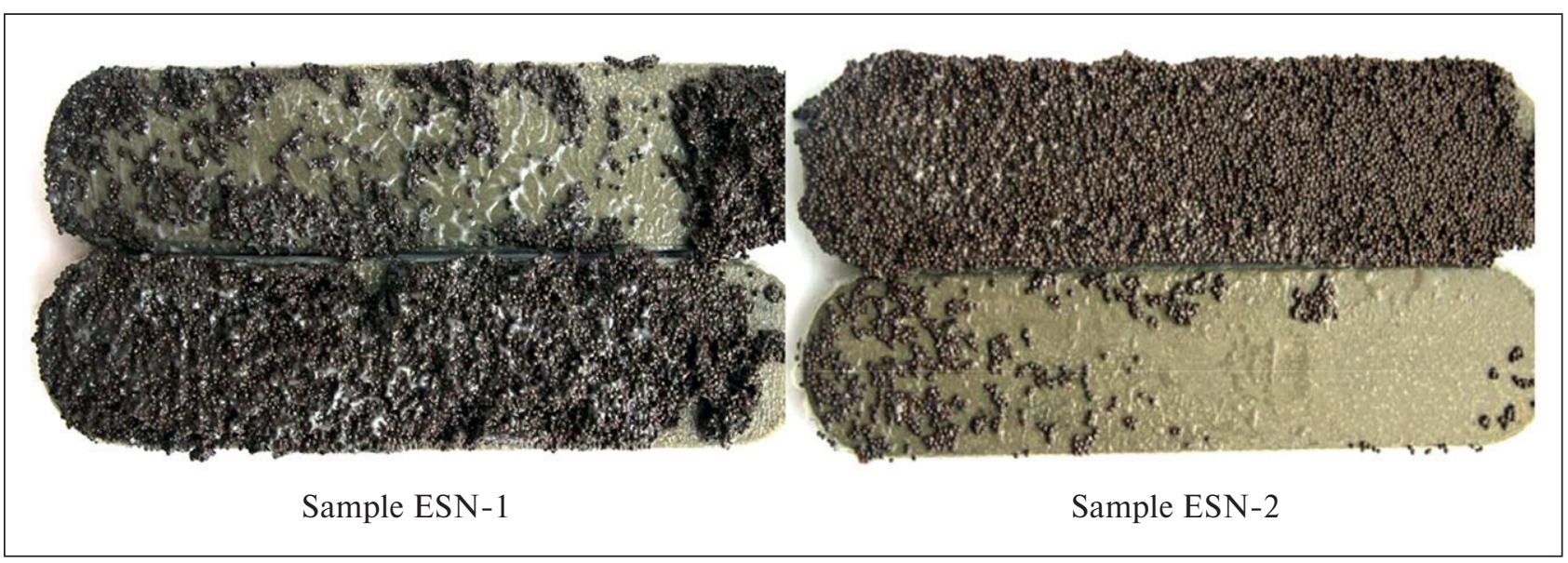

Fig. 2. Visual appearance of ESN-1 and ESN-2 inside the disassembled hydraulic fracture models

Table 3

Assessment of ESN influence on the filtration characteristics of fracturing models of Abdylovskoe and Yugomashevskoe oil-gas fields

\begin{tabular}{|c|c|c|c|c|c|c|c|}
\hline \multirow{2}{*}{$\begin{array}{c}\text { Sample } \\
\text { name }\end{array}$} & \multirow{2}{*}{$\begin{array}{c}\text { Proppant } \\
\text { fraction }\end{array}$} & $\begin{array}{c}\text { Effective } \\
\text { pressure, } \\
\text { MPa }\end{array}$ & \multicolumn{2}{|c|}{ Conductivity, $\mathbf{m D} \cdot \mathbf{m}$} & Permeability, Darcy & Permeability \\
\cline { 5 - 8 } & & Before & After & Before & After & times \\
\hline ESN-1 & $16 / 20$ & 8 & 76738 & 3331 & 1131 & 49 & 23 \\
\hline ESN-2 & $16 / 20$ & 8 & 86307 & 4809 & 1365 & 77 & 18 \\
\hline
\end{tabular}

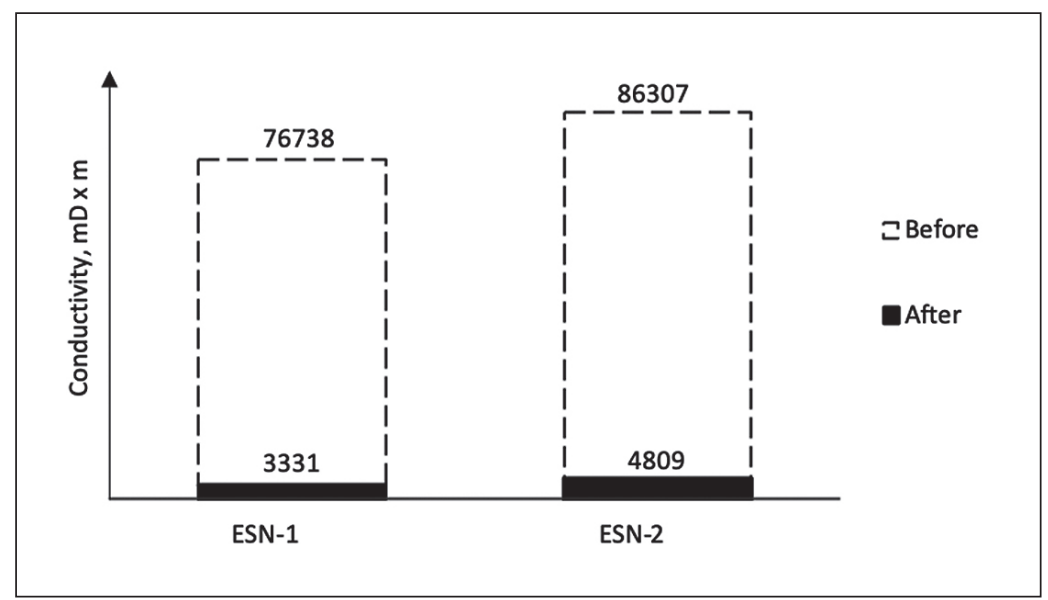

Fig. 3. Assessment of ESN influence on the conductivity of fracturing models of Abdylovskoe and Yugomashevskoe oil-gas fields (CarboProp 16/20) 


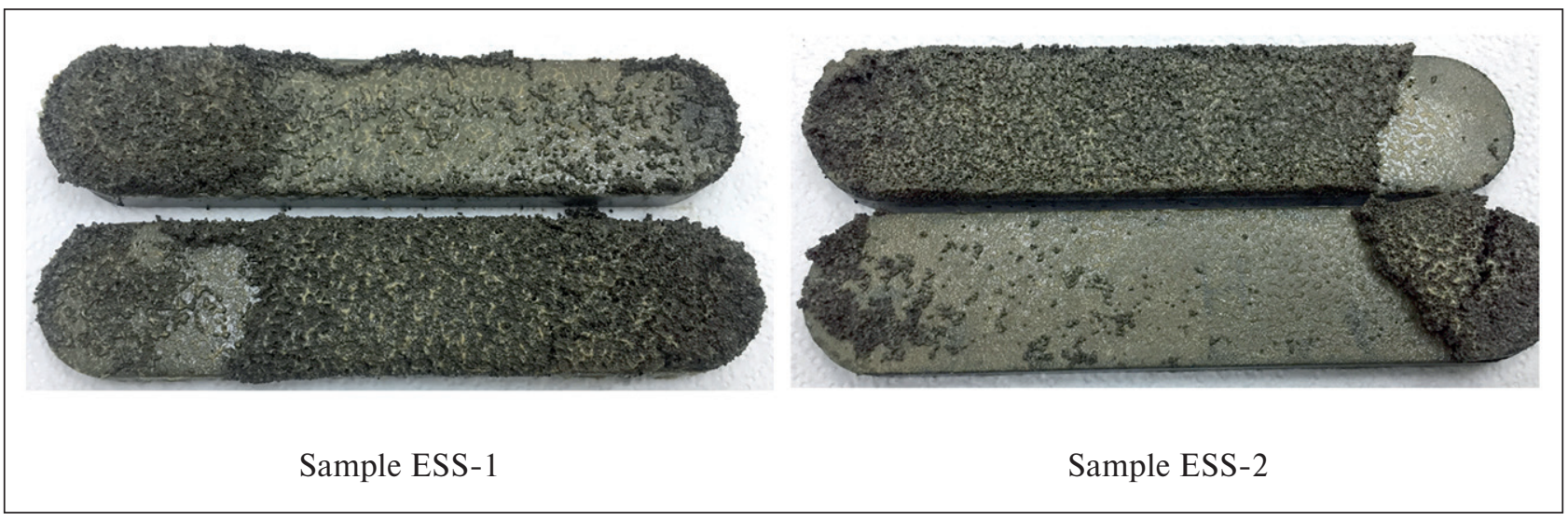

Fig. 4. Visual appearance of ESS-1 and ESS-2 inside the disassembled hydraulic fracture models

Table 4

Assessment of ESS influence on the filtration characteristics of fracturing models of Tortasinskoe oil-gas field

\begin{tabular}{|c|c|c|c|c|c|c|c|}
\hline \multirow{2}{*}{$\begin{array}{c}\text { Sample } \\
\text { name }\end{array}$} & \multirow{2}{*}{$\begin{array}{c}\text { Proppant } \\
\text { fraction }\end{array}$} & \multirow{2}{*}{$\begin{array}{c}\text { Effective } \\
\text { pressure, } \\
\text { MPa }\end{array}$} & \multicolumn{2}{|c|}{ Conductivity, $\mathbf{m D} \cdot \mathbf{m}$} & \multicolumn{2}{|c|}{ Permeability, Darcy } & Permeabil- \\
\cline { 6 - 8 } & & & Before & After & Before & After & $\begin{array}{c}\text { ity reduc- } \\
\text { tion, times }\end{array}$ \\
\hline ESS-1 & $20 / 40$ & 19.9 & 2430 & 36 & 397 & 6 & 66 \\
\hline ESS-2 & $20 / 40$ & 19.9 & 2480 & 10 & 389 & 2 & 237 \\
\hline
\end{tabular}

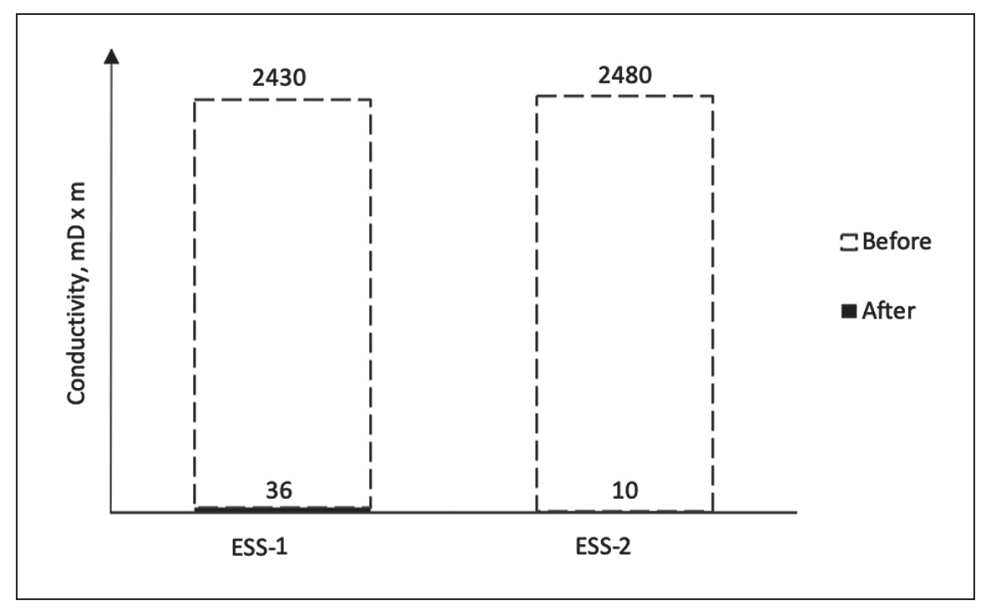

Fig. 5. Assessment of ESS influence on the conductivity of fracturing models of Tortasinskoe oil-gas field (CarboProp 20/40)

According to the results of filtration experiments, it was determined that ESS systems effectively block filtration of water in highly permeable fracturing models fixed with CarboProp proppant fraction 20/40 (Fig. 5). The reduction in conductivity and permeability of hydraulic fracture models is as following: for ESS-1 - 68 and 66 times; for ESS-2 - 238 and 237 times, respectively.

\section{CONCLUSION}

The results of the series of carried out filtration experiments made it possible to study and evaluate water-limiting and blocking properties of colloidal systems in forms of emulsion and emulsion-suspension systems with a content of solid nanosized particles 
up to 1.5 vol. \%. It was determined that the filtration of ESN and ESS systems in models of superconducting hydraulic fractures with permeability from 397 Darcy with proppant CarboProp fraction 20/40 for Tortasinskoe field up to 1365 Darcy with proppant CarboProp fraction 16/20 for Abdylovskoe and Yugomashevskoe oil-gas fields leads to a significant decrease in filtration parameters of the proppant pack for an aqueous solution of potassium chloride. Thus, a reduction in conductivity of hydraulic fracture models for proppant $16 / 20$ is 23 times for the ESN-1 sample and 18 times for the ESN-2 sample. For the proppant fraction 20/40 a reduction in conductivity is 66 times for the ESS-1 and 237 times for the ESS-2. These results indicate potentially high technological efficiency of the developed ESN and ESS systems implementation in upstream oil $\&$ gas for intensification of oil production, enhanced oil recovery, construction and workover of oil and gas wells. Depending on the purpose of application of the developed systems, tasks to be solved and reservoir conditions an optimal concentration of nanoparticles for ESN can be in the range from 0.5 to $1.0 \mathrm{vol}$. \%, and for ESS in the range from 0.5 to $1.5 \mathrm{vol}$. $\%$. However, the optimal concentrations of both solid and liquid phases of these newly developed colloidal systems should be clarified by the results of pilot tests and further industrial scaling up.

\section{REFERENCES}

1. Nguyen, D., Wang, D., Oladapo, A., Zhang, J., Sickorez, J., Butler, R., \& Mueller, B. (2014, April 12). Evaluation of Surfactants for Oil Recovery Potential in Shale Reservoirs. Society of Petroleum Engineers. doi:10.2118/169085-MS.

2. Alvarez, J.O., \& Schechter, D.S. (2016, April 11). Altering Wettability in Bakken Shale by Surfactant Additives and Potential of Improving Oil Recovery During Injection of Completion Fluids. Society of Petroleum Engineers. doi:10.2118/179688-MS.

3. Taheri, M., Bonto, M., Eftekhari, A.A., \& M. Nick, H. (2019, March 15). Towards Identifying the Mechanisms of the Modified-Salinity Waterflooding by a Novel Combination of Core flooding and Mathematical Modeling. Society of Petroleum Engineers. doi:10.2118/195110-MS.

4. Downs, J., \& Fleming, N. (2018, February 7). Evaluating Formation Damage Predictions Drawn from HPHT Core Flooding Tests on Brent Group Sandstone Reservoir Cores with Heavy Formate Drill-in Fluids: A Case Study from the Huldra Field. Society of Petroleum Engineers. doi:10.2118/189530-MS.

5. Al-Saedi, H.N., Al-Jaberi, S. K., Al-Bazzaz, W., \& Flori, R.E. (2019, October 21). Experimental Study of Flooding both Low Salinity Water and Foam in Sandstone Reservoirs Bearing Heavy Crude Oil. Society of Petroleum Engineers. doi:10.2118/198675-MS.

6. Sergeev, V., Kim, I., Zeigman, J., \& Yakubov, R. (2018, November 12). Innovative Water-Limiting Agent Based on High Stable Emulsion with Nanoparticles for IOR Implementation. Society of Petroleum Engineers. doi:10.2118/192742-MS.

7. Sergeev V.V., Russkikh K.G., Zeigman Y.V., Yakubov R.N. Experimental research of the impact of filtration processes on the dispersity of emulsion systems with nanoparticles. Nanotechnologies in Construction. 2019, Vol. 11, no.1, pp. 31-41. DOI: 10.15828/2075-8545-2019-11-1-31-41.

8. Sergeev V.V., Zainullin I.I., Zeigman Y.V., Yakubov R.N. Research for the selective- ness of emulsion systems with $\mathrm{SiO}_{2}$ nanoparticles. Nanotechnologies in Construction. 2018, Vol. 10, no. 6, pp. 18-44. DOI: dx.doi. org/10.15828/2075-8545-201810-6-18-44.

9. Shah, S.Y., As Syukri, H., Wolf, K.-H., Pilus, R.M., \& Rossen, W.R. (2020, February 1). Foam Generation in Flow Across a Sharp Permeability Transition: Effect of Velocity and Fractional Flow. Society of Petroleum Engineers. doi:10.2118/195517-PA.

10. Korovin K.V., Pecherin T.N. Experience and prospects of applying chemical oil recovery enhancement technologies in the Khanty-Mansiysk Autonomous Okrug - YuGRA // Fundamental Research. - 2016. - No. 12-5. - p. 993-997. (In Russian).

11. Kryanev D.Yu. Oil recovery enhancement methods: experience and application prospects / Kryanev D.Yu., Zhdanov S.A. // Oil and gas vertical. 2011. No 5. (In Russian).

12. Zemtsov Yu.V. A review of the physicochemical EOR used in Western Siberia and the effectiveness of their use in various geological and physical conditions / Zemtsov Yu.V., Baranov A.V., Gordeev A.O. // Oil. Gas. Novation. 2015. No. 7. p. $11-122$. (In Russian).

13. Overview of the Russian oilfield services market - 2019. Deloitte CIS Research Center Moscow. 2019. 36 p.

14. Key trends in the market of research and development in the oil and gas industry of Russia - 2014 Deloitte CIS Research Center Moscow. 2014. 16 p.

15. Zeigman Y.V., Mukhametshin V.Sh., Sergeev V.V., Kinzyabaev F.S. Experimental study of viscosity properties of emulsion system with $\mathrm{SiO}_{2}$ nanoparticles. Nanotechnologies in Construction. 2017, Vol. 9, no. 2, pp. 16-38. DOI: dx.doi.org/10.15828/20758545-2017-9-2-16-38. 


\section{THE RESULTS OF THE SPECIALISTS' AND SCIENTISTS' RESEARCHES}

16. Zeigman Yu.V., Belenkova N.G., Sergeev V.V. Experimental research of stability of emulsion systems with $\mathrm{SIO}_{2}$ nanoparticles. Nanotechnologies in Construction. 2017, Vol. 9, no. 5, pp. 36-52. DOI: dx.doi. org/10.15828/2075-8545-2017-9-5-36-52. (In Russian).

17. Sergeev V.V., Belenkova N.G., Zeigman Yu.V., Mukhametshin V.Sh. Physical proper- ties of emulsion systems with $\mathrm{SiO}_{2}$ nanoparticles. Nanotechnologies in Construction. 2017, Vol. 9, no. 6, pp. 37-64. DOI: dx.doi. org/10.15828/2075-8545-2017-96-37-64.

18. V. Sergeev, K. Tanimoto, and M. Abe. The Water-blocking Agent with Improved Properties for IOR Implementation. Conference Proceedings, IOR $2019-20^{\text {th }}$ European Symposium on Improved Oil Recovery, Apr. 2019, Volume 2019 , p. 1-11. European Association of Geoscientists \& Engineers. Doi.org/10.3997/2214-4609.201900162.

19. Sergeev, V., Tanimoto, K., \& Abe, M. (2019, November 11). Innovative Emulsion-Suspension Systems Based on Nanoparticles for Drilling and Well Workover Operation. Society of Petroleum Engineers. doi:10.2118/197510-MS.

20. GOST R 51761-2013 (2014) National standard of the Russian Federation. Aluminosilicate proppants. Technical specifications. (In Russian).

21. GOST 8.417-2002 (2003) Interstate Standard. State system for ensuring uniformity of measurements. Units of quantities (entered into force by Resolution of the State Standard of the Russian Federation of 04.02.2003 No. 38-ct). (In Russian).

22. ISO 13503-5:2006 (2006) Petroleum and natural gas industries - Completion fluids and materials - Part 5: Procedures for measuring the long-term conductivity of proppants.

\section{INFORMATION ABOUT THE AUTHORS}

Vitaly V. Sergeev, Cand. Sci. (Eng.), Head of innovations, VI-ENERGY LLC, Skolkovo Foundation, Nobel st., 5, office 225, Skolkovo Innovation Center, Moscow, 121205, Russia, sergeev@vi-energy.ru

Rinat R. Sharapov, Head of laboratory of geomechanics research, RN-BashNIPIneft LLC, Lenin st., 86/1, Ufa, Bashkortostan Republic, 450006, Russia, sharapovrr@bashneft.ru

Alexey Y. Kudymov, Head of sector of rocks geomechanics research, Tyumen Oil Research Center LLC, Tyumen, Tyumen Region, 625048, Russia, aykudymov@tnnc.rosneft.ru

Yury V. Zeigman, Dr. Sci. (Eng), Professor, Head of oil-gas fields development department, Ufa State Petroleum Technological University, Kosmonavtov st., 1, Ufa, Bashkortostan Republic, 450062, Russia, jvzeigman@gmail.com

Vyacheslav S. Mukhametshin, Dr. Sci. (Eng), Professor, Ufa State Petroleum Technological University, Devonskaya St., 54A, Oktyabrsky, Bashkortostan Republic, 452600, Russia, vsh@of.ugntu.ru 


\title{
Экспериментальное исследование влияния коллоидных систем с наночастицами на фильтрационные характеристики трещин гидравлического разрыва пласта
}

\author{
B.В. Сергеев ${ }^{1 *}$ (D), Р.P. Шарапов ${ }^{2}$, А.Ю. Кудымов ${ }^{3}$, Ю.В. Зейгман ${ }^{4}$, В.Ш. Мухаметшин ${ }^{5}$ \\ 1 ООО «ВИ-ЭНЕРДЖИ», Фонд «Сколково», г. Москва, Россия; \\ ${ }^{2} \mathrm{OОO}$ «РН-БашНИПИнефть», г. Уфа, Республика Башкортостан, Россия; \\ ${ }^{3} \mathrm{OOO}$ «ТННЦ», г. Тюмень, Тюменская область, Россия; \\ ${ }^{4}$ ФГБОУ ВО «Уфимский государственный нефтяной технический университет», \\ г. Уфа, Республика Башкортостан, Россия; \\ ${ }^{5}$ Филиал ФГБОУ ВО «Уфимский государственный нефтяной технический университет» В г. Октябрьский, \\ г. Октябрьский, Республика Башкортостан, Россия \\ * Контакты: e-mail: sergeev@vi-energy.ru \\ (с) Коллектив авторов, 2020
}

PEЗЮME: Коллоидные системы в виде эмульсий или суспензий нашли широкое применение в различных отраслях промышленности, в том числе в отрасли разработки нефтегазовых месторождений. Обратные эмульсии и суспензии активно применяются в процессах разработки месторождений, включая такие направления, как увеличение нефтеотдачи пластов, интенсификация добычи нефти, строительство и подземный ремонт скважин. В данной статье представлены результаты лабораторных экспериментов по исследованию физических свойств гетерогенных систем двух типов: эмульсионная система с наночастицами; эмульсионно-суспензионная система с наночастицами. Данные коллоидные системы обладают уникальными физико-химическими свойствами и могут быть эффективно применимы в процессах разработки месторождений в качестве водоограничивающего или блокирующего агентов обратимого действия. В рамках проведенных лабораторных экспериментов произведена оценка влияния новых систем на фильтрационные характеристики моделей трещин гидравлического разрыва пласта. Эксперименты поставлены в соответствии с требованиями международных стандартов и выполнены в условиях, максимально приближенных к пластовым термобарическим условиям объектов $C_{\text {тур }}$ Абдуловского, С и ЮС-2, ЮС-4 Тортасинского месторождений. По результатам экспериментов рассчитаны коэффициенты проницаемости и проводимости моделей до и после фильтрации коллоидных систем нового типа. С целью оценки технологичности новых систем и возможности регулирования тампонирующих свойств проведен анализ влияния вида и количества твердых наноразмерных частиц на блокирующие свойства систем. Представлены оптимальные концентрации наночастиц в композициях для различных условий карбонатных и терригенных пластов нефтегазовых месторождений Российской Федерации.

КЛЮчЕВЫЕ СЛОВА: наночастицы, двуокись кремния, эмульсионная система, эмульсионно-суспензионная система, гидроразрыв пласта.

для цитиРОВАния: Сергеев В.В., Шарапов Р.Р., Кудымов А.Ю., Зейгман Ю.В., Мухаметшин В.Ш. Экспериментальное исследование влияния коллоидных систем с наночастицами на фильтрационные характеристики трещин гидравлического разрыва пласта // Нанотехнологии в строительстве. - 2020. - Том 12, № 2. - С. 100-107. - DOI: 10.15828/2075-8545-2020-12-2-100-107.

\section{ВВЕДЕНИЕ}

$\mathrm{C}$ Современный мировой уровень развития экспериментальных методов моделирования фильтрации жидкостей в пористых средах позволяет исследовать процессы фильтрации с высокой степенью приближенности к природным условиям залегания подземных пластов [1-9]. Постоянное совершенствование и развитие данного направления экспериментальных исследований обуславливается совершенствованием государственных стандартов в области промышленной безопасности и охраны 
окружающей среды, а также поддерживается требованиями промышленных предприятий к качеству результатов лабораторных исследований и постоянно растущим спросом нефтегазодобывающей промышленности на разработку новых водоограничивающих составов и технологий их применения в скважинах с ГРП [10-14]. К примеру, на сегодняшний день, в Российской Федерации большинство предприятий нефтегазодобывающей промышленности установили локально-нормативные требования к перечню и методикам лабораторных испытаний новых химических продуктов. В рамках данных требований новая химическая продукция, предназначенная для закачки в подземные пласты, должна быть испытана на предмет совместимости с технологическими жидкостями, пластовыми флюидами, горными породами и расклинивающими материалам, а также оценена с точки зрения влияния на фильтрационно-емкостные характеристики трещин ГРП в условиях, максимально приближенных к пластовым.

Результаты исследований, представленные в статье, получены в рамках реализации опытно-промышленных проектов по внедрению водоограничивающего агента в виде эмульсионной системы с наночастицами [15-18], а также блокирующего агента в виде эмульсионно-суспензионной системы с наночастицами [19] на ряде нефтегазовых месторождений Российской Федерации. Геолого-физические характеристики нефтегазоносных пластов рассматривае- мых месторождений характеризуются значительной разницей в пластовых температурах от 22 до $98^{\circ} \mathrm{C}$ и давлениях от 8 до $39 \mathrm{MPa}$. С целью моделирования пластовых условий трещин гидравлического разрыва пласта (ГРП) в экспериментах применялся пропант марки CarboProp фракции 16/20 для объектов $\mathrm{C}_{\text {Тур }}$ Абдуловского и $\mathrm{C}_{\text {БАш }}$ Югомашевского месторождений, CarboProp фракции 20/40 для пластов ЮС-2, ЮС-4 Тортасинского месторождения.

\section{МЕТОДИЧЕСКАЯ И ПОДГОТОВИТЕЛЬНАЯ ЧАСТЬ}

На этапе подготовки материалов и технологических жидкостей к проведению экспериментов производили приготовление следующих лабораторных образцов коллоидных систем: эмульсионная система с наночастицами двуокиси кремния (ЭСН), применяемая в качестве водоограничивающего агента в технологиях интенсификации добычи нефти и увеличения нефтеотдачи; эмульсионно-суспензионная система с наночастицами двуокиси кремния (ЭСС), применяемая в качестве блокирующей пачки в процессах строительства и подземного ремонта нефтяных и газовых скважин. Информация по содержанию водной и твердой фаз в составах образцов приведена в табл. 1.

Краткая характеристика пластовых условий Югомашевского, Абдуловского и Тортасинского нефтегазовых месторождений приведена в табл. 2.

\section{Таблица 1}

Содержание наночастиц двуокиси кремния и воды в составах лабораторных образцов коллоидных систем

\begin{tabular}{|c|c|c|}
\hline Наименование образца & $\begin{array}{c}\text { Содержание наночастиц } \\
\text { двуокиси кремния, \% об. }\end{array}$ & $\begin{array}{c}\text { Содержание модели жидкости } \\
\text { глушения, \% об. }\end{array}$ \\
\hline ЭСН-1 & 0,5 & 81,5 \\
\hline ЭСН-2 & 1,0 & 71 \\
\hline ЭСС-1 & 0,5 & 89,5 \\
\hline ЭСС-2 & 1,5 & 85,5 \\
\hline
\end{tabular}

Таблица 2

Краткая характеристика пластовых условий Югомашевского, Абдуловского и Тортасинского нефтегазовых месторождений

\begin{tabular}{|c|c|c|c|c|c|}
\hline Месторождение & Объект/пласт & Горные породы & $\begin{array}{c}\text { Пластовое } \\
\text { давление, МПа }\end{array}$ & Температура, ${ }^{\circ} \mathbf{C}$ & $\begin{array}{c}\text { Фракция } \\
\text { пропанта }\end{array}$ \\
\hline Абдуловское & $\mathrm{C}_{\text {Тур }}$ & Карбонатные & 8,0 & 27 & $16 / 20$ \\
\hline Югомашевское & $\mathrm{C}_{\text {БАш }}$ & Карбонатные & 8,0 & 22 & $16 / 20$ \\
\hline Тортасинское & ЮС-2/ЮС-4 & Терригенные & $35,5 / 39,5$ & $97,8 / 98$ & $20 / 40$ \\
\hline
\end{tabular}




\section{Методика определения насыпной плотности про- панта}

Определение насыпной плотности пропанта проводили согласно ГОСТ Р 51761-2013 «Пропанты алюмосиликатные. Технические условия» [20]. Исследования и расчеты выполнялись с учетом ГОСТ 8.417-2002 «Межгосударственный стандарт. Государственная система обеспечения единства измерений. Единицы величин» [21].

Эксперименты по определению насыпной плотности пропанта проводили при комнатной температуре. В воронку, выходное отверстие которой было закрыто резиновым стопорным шариком, насыпали $150 \mathrm{~cm}^{3}$ пробы для испытаний. Под центром выходного отверстия воронки помещали калиброванный цилиндр. Перемещая резиновый шарик влево или вправо, выпускали весь объем пропантов в цилиндр. Излишек пропанта в калиброванном цилиндре аккуратно снимали стеклянной пластиной по кромке цилиндра без встряхивания и трамбования. Взвешивали калиброванный цилиндр с пробой и стеклянной пластиной, записывали массу в граммах. (1):

Насыпную плотность $\rho_{\text {нсп }}$ вычисляли по формуле

$$
\rho_{\text {нсп }}=\frac{m_{\text {о.п. }}-m_{\text {о.с. }}}{V},
$$

где $m_{\text {о.п. }}$ - общая масса цилиндра с пробой и пластиной, г;

$m_{\text {о.с. }}$ - общая масса сухого цилиндра и пластины, г;

$V$ - объем цилиндра, см$^{3}$.

За результат определений принимали среднее арифметическое значение результатов двух параллельных испытаний.

По результатам исследований насыпная плотность пропантов марки CarboProp фракции 20/40

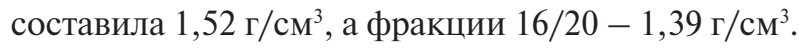

\section{Методика определения остаточной проводимости модели трещины ГРП}

Эксперименты по определению проводимости модели трещины ГРП (пропантная упаковка) проводились согласно стандарту ISO 13503-5:2006 [22].

Перед проведением экспериментов производили подготовку пластин керна «Оhio» и рабочего раствора $-2 \%$ водный раствор хлорида калия.

Пластины помещали в специальную ячейку, заполняли пустотное пространство между стенками ячейки и пластинами керна двухкомпонентным герметиком. Далее вакуумировали ячейку в течение часа, затем помещали в термошкаф с температурой $75^{\circ} \mathrm{C}$ на 4 часа, для вулканизации состава. После из- влечения пластин керна из термошкафа излишки состава удалялись, оставляя тонкий слой по торцам образца.

С целью снижения коррозионной активности рабочего раствора проводили вакуумирование $2 \%$ водного раствора хлорида калия в течение 3 часов, затем производили насыщение азотом в течение не менее 1 часа. Данную процедуру проводили не менее 3 раз.

После проведения подготовительных работ начинали проведение теста по определению остаточной проводимости модели трещины ГРП в указанном ниже порядке.

В ячейку для исследования проводимости пропантной упаковки помещали керн «Ohio», между пластинами засыпали пропант марки CarboProp coответствующей фракции с необходимой концентрацией пропанта. Расчет количества пропанта производили по формуле (2):

$$
\mathrm{M}_{\mathrm{n}}=6,452 \cdot \mathrm{C}
$$

где $\mathrm{M}_{\text {п }}$ - масса пропанта, г;

$\mathrm{C}$ - нагрузка на пропант, кг/ $\mathrm{M}^{2}$.

Ячейка с пропантом и керном помещалась в пресс, подсоединялись датчики деформации, трубки подачи флюида и датчики измерения перепада давления. Производили нагрев и стабилизацию всей системы до пластовой температуры. Схема модели трещины ГРП (пропантной упаковки) приведена на рис. 1.

Далее производили первоначальное нагружение системы до значений 6,9 МПа, проверку герметичности сборки с давлением прокачки 3,45 МПа. После проверки на герметичность насыщали пропантную пачку раствором хлорида калия. После выдержки в течение 12 часов проводили измерение ширины, проводимости и проницаемости пропантной упаковки при разных расходах прокачки рабочего флюида.

Фильтрационные характеристики пропантной упаковки определяли в течение 1 ч (до стабилизации перепада давления). Проводимость пропантной упаковки замеряли на скоростях потока, соответствующих перепаду давления от 0,01 до 0,03 кПа. Проводимость рассчитывали по формуле (3)

$$
k W_{\mathrm{y}}=5,554 \cdot \mu \cdot Q \cdot L / \Delta P,
$$

где $k W_{\text {y }}$ - проводимость пропантной пачки, $\mathrm{MKM}^{2} \bullet \mathrm{cM}$;

$\mu-$ вязкость испытательной жидкости при температуре испытания, сПз;

$Q-$ расход, см ${ }^{3}$ миин;

$\Delta P$ - перепад давления, кПа;

$L-$ длина между портами, см.

Проницаемость рассчитывалась по формуле (4): 


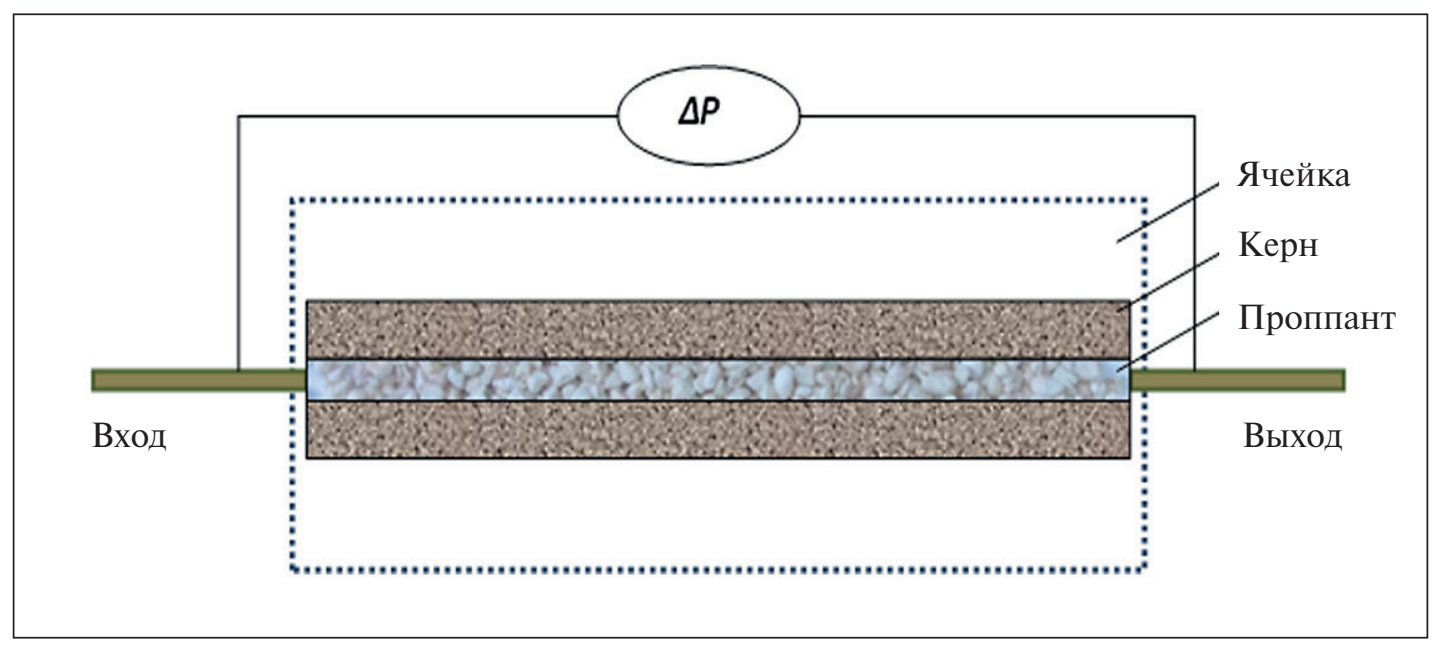

Рис. 1. Схематическое изображение модели трещины ГРП

$$
k=100 \cdot \mu \cdot Q \cdot L \cdot\left[w \cdot(\Delta P) \cdot W_{\mathrm{y}}\right]
$$

где $k$ - проницаемость пропантной пачки, мкм²; $\mu-$ вязкость испытательной жидкости при температуре испытания, сПз;

$Q-$ расход, см$^{3} /$ мин;

$\Delta P-$ перепад давления, кПа;

$L$ - длина между портами, см;

$W_{\mathrm{y}}$ - ширина пропантной пачки, см;

$w$ - ширина ячейки, см.

Далее производили подъем давления смыкания трещины до величины эффективного напряжения смыкания, равного 20 МПа, с последующей выдержкой в течение 48 часов. Измеряли ширину, проводимость и проницаемость пропантной упаковки при разных расходах прокачки рабочего флюида. Рассчитывали проводимость и проницаемость пропантной пачки по формулам (3) и (4).

Далее прокачивали блокирующий состав в объеме $200 \mathrm{~cm}^{3}$. Производили технический отстой в течение 2 часов и процедуру промывки пропантной упаковки путем фильтрации рабочего раствора в объеме $1000 \mathrm{~cm}^{3}$ при расходе $5 \mathrm{~cm}^{3}$ мин при постепенном наращивании давления на входе в трещину до максимального или давления прорыва воды с фиксацией динамики процесса.

Проводили измерение проводимости и проницаемости пропантной упаковки при разных расходах прокачки рабочего флюида. Фильтрационные характеристики пропантной упаковки определялись в течение 1 ч (до установления перепада давления). Рассчитывали проводимость и проницаемость пропантной пачки по формулам (3) и (4).

После замера проводимости и проницаемости пропантной упаковки система переводилась в атмосферные условия, производили разборку и очистку ячейки.
По полученным результатам проводимости и проницаемости до и после фильтрации блокирующего состава производился расчет коэффициентов восстановления проводимости и проницаемости пропантной упаковки по формулам (5) и (6):

$$
\begin{aligned}
& K_{\mathrm{B}_{k W \mathrm{y}}}=k W_{\mathrm{y} 2} / k W_{\mathrm{y} 1}, \\
& K_{\mathrm{B}_{k}}=k_{2} / k_{1},
\end{aligned}
$$

где $K_{\mathrm{B}_{k W y}}-$ коэффициент восстановления проводимости, \%;

$K_{\mathrm{B}_{k}}-$ коэффициент восстановления проницаемости, \%;

$k W_{\mathrm{y1}}$ - проводимость модели трещины ГРП до прокачки блокирующего состава, мкм² • см;

$k W_{\text {у2 }}-$ проводимость модели трещины ГРП после прокачки блокирующего состава, мкм² • см;

$k_{1}$ - проницаемость модели трещины ГРП до прокачки блокирующего состава, мкм²;

$k_{2}$ - проницаемость модели трещины ГРП после прокачки блокирующего состава, мкм².

Фильтрационные эксперименты выполнялись на программно-измерительном комплексе ПИКAPI-RP-61, предназначенном для измерения следующих фильтрационных характеристик пропантной упаковки в термобарических условиях:

- измерение долговременной проводимости;

- измерение остаточной проводимости;

- измерение остаточной проницаемости;

- испытания блокирующих составов и деструкторов в условиях, моделирующих пластовые;

- сопротивление раздавливанию.

Установка позволяла проводить испытания при давлении смыкания до 100 тонн, максимальном давлении прокачки 10 МПа и температуре $150^{\circ} \mathrm{C}$. 


\section{РЕЗУЛЬТАТЫ И НАБЛЮДЕНИЯ}

С целью исследования водоограничивающих свойств ЭСН, применяемой в технологиях интенсификации добычи нефти и увеличения нефтеотдачи пластов, было проведено два эксперимента по определению остаточной проводимости моделей трещин ГРП Югомашевского и Абдуловского нефтегазовых месторождений. В данных экспериментах поровое давление составляло 3,45 МПа. Условия проведения экспериментов и концентрация наночастиц в системах ЭСН-1 и ЭСН-2 приведены в табл. 1 и 2. Фотографии моделей трещин ГРП после разбора представлены на рис. 2.

Результаты экспериментов по исследованию влияния водоограничивающего агента ЭСН на фильтрационные характеристики моделей трещин ГРП приведены в табл. 3 и на рис. 3.

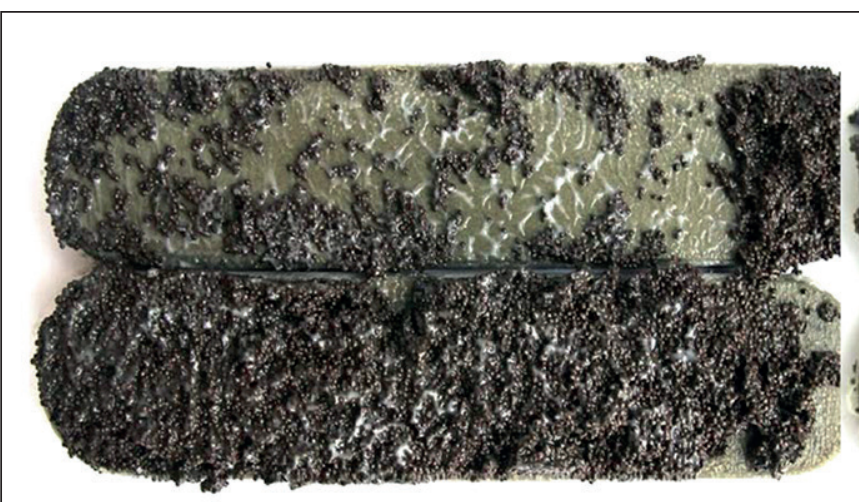

Образец ЭСН-1

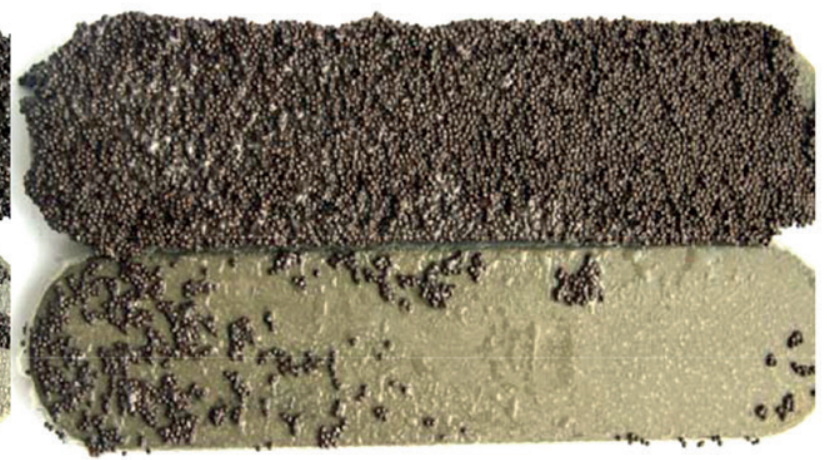

Образец ЭСН-2

Рис. 2. Внешний ЭСН-1 и ЭСН-2 в моделях трещин ГРП после разбора

Таблица 3

Оценка влияния ЭСН на фильтрационные характеристики моделей трещин ГРП Югомашевского и Абдуловского нефтегазовых месторождений

\begin{tabular}{|c|c|c|c|c|c|c|c|}
\hline \multirow{2}{*}{$\begin{array}{c}\text { Наимено- } \\
\text { вание об- } \\
\text { разца }\end{array}$} & \multirow{2}{*}{$\begin{array}{l}\text { Фракция } \\
\text { пропанта }\end{array}$} & \multirow{2}{*}{$\begin{array}{c}\text { Давление } \\
\text { в трещине, } \\
\text { МПа }\end{array}$} & \multicolumn{2}{|c|}{ Проводимость, мД• м } & \multicolumn{2}{|c|}{ Проницаемость, Дарси } & \multirow{2}{*}{$\begin{array}{c}\text { Снижение } \\
\text { проницаемо- } \\
\text { сти, раз }\end{array}$} \\
\hline & & & До & После & До & После & \\
\hline ЭСН-1 & $16 / 20$ & 8 & 76738 & 3331 & 1131 & 49 & 23 \\
\hline ЭСH-2 & $16 / 20$ & 8 & 86307 & 4809 & 1365 & 77 & 18 \\
\hline
\end{tabular}

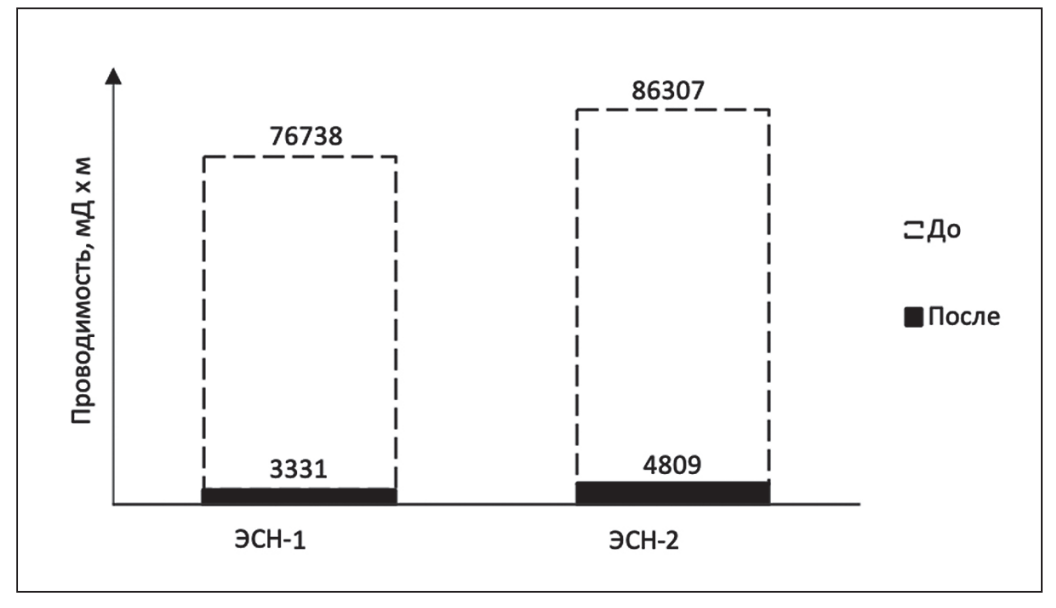

Рис. 3. Оценка влияния ЭСН на проводимость моделей трещин ГРП Абдуловского и Югомашевского нефтегазовых месторождений (CarboProp 16/20) 
По результатам проведения фильтрационных экспериментов определено, что системы ЭСН значительно ограничивают фильтрацию воды в высокопроницаемых моделях трещин ГРП, закрепленных пропантом CarboProp фракции 16/20 (рис. 3). Снижение проводимости и проницаемости моделей трещин ГРП составило: для ЭСН-1 в 23 раза; для ЭСН-2 в 18 раз.

С целью исследования блокирующих свойств ЭСС, применяемой в процессах строительства и подземного ремонта нефтяных и газовых скважин, было проведено два эксперимента по определению остаточ- ной проводимости моделей трещин ГРП Тортасинского нефтегазового месторождения. В данных экспериментах поровое давление составляло 3,45 МПа. Условия проведения экспериментов и концентрация наночастиц в системах ЭСС-1 и ЭСС-2 приведены в табл. 1 и 2. Фотографии моделей трещин ГРП после разбора представлены на рис. 4.

Результаты экспериментов по исследованию влияния блокирующего агента ЭСС на фильтрационные характеристики моделей трещин ГРП Тортасинского нефтегазового месторождения приведены в табл. 4 и на рис. 5.

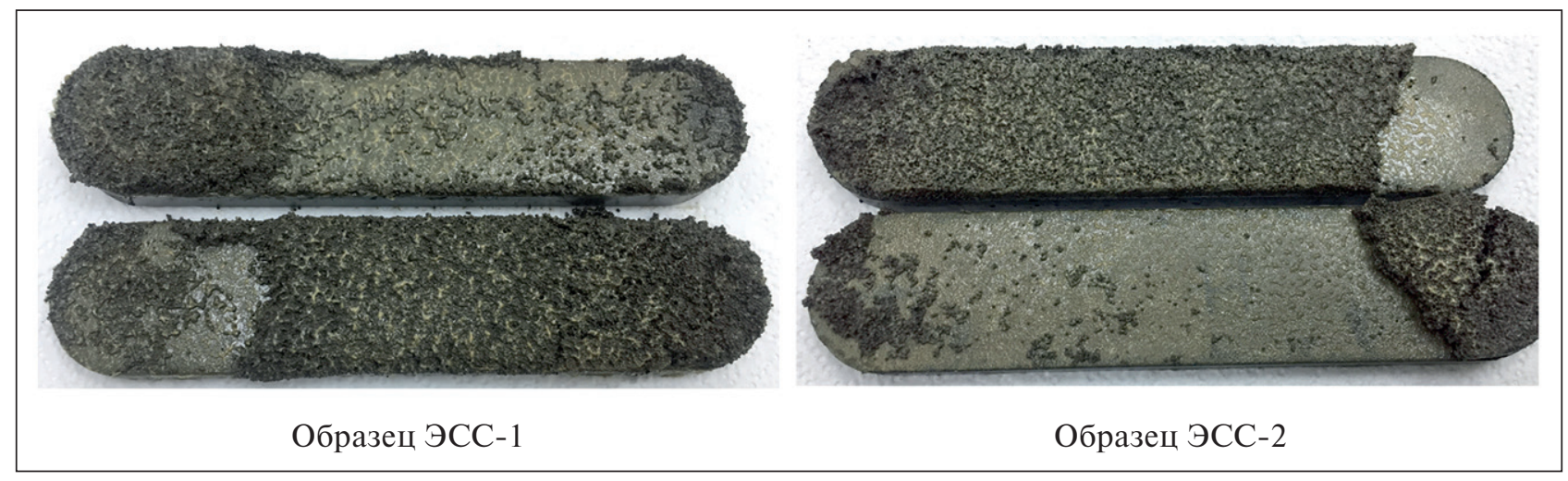

Рис. 4. Внешний ЭСС-1 и ЭСС-2 в моделях трещин ГРП после разбора

\section{Таблица 4}

Оценка влияния ЭСС на фильтрационные характеристики моделей трещин ГРП Тортасинского нефтегазового месторождения

\begin{tabular}{|c|c|c|c|c|c|c|c|}
\hline \multirow{2}{*}{$\begin{array}{c}\text { Наимено- } \\
\text { вание об- } \\
\text { разца }\end{array}$} & \multirow{2}{*}{ Фракция } & \multirow{2}{*}{ Давление } & \multicolumn{2}{|c|}{ Проводимоста } \\
\cline { 5 - 8 } & п трещине, & МПа & До & После & До & После & $\begin{array}{c}\text { Пноницицае- } \\
\text { мости, раз }\end{array}$ \\
\hline ЭСС-1 & $20 / 40$ & 19.9 & 2430 & 36 & 397 & 6 & 66 \\
\hline ЭСС-2 & $20 / 40$ & 19.9 & 2480 & 10 & 389 & 2 & 237 \\
\hline
\end{tabular}

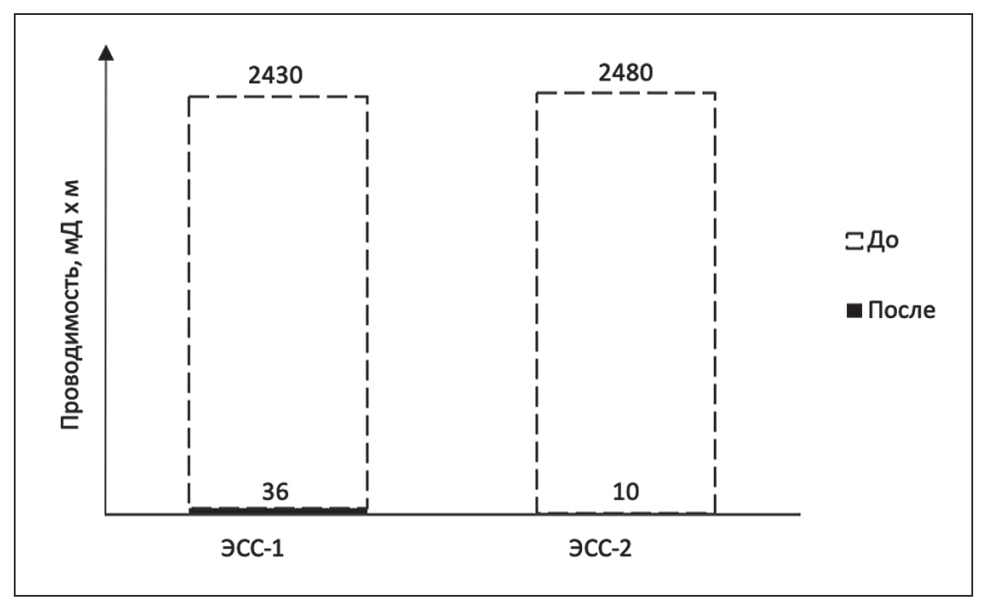

Рис. 5. Оценка влияния ЭСС на проводимость моделей трещин ГРП Тортасинского нефтегазового месторождения (CarboProp 20/40) 
По результатам проведения фильтрационных экспериментов определено, что системы ЭСС эффективно блокируют фильтрацию воды в высокопроницаемых моделях трещин ГРП, закрепленных пропантом CarboProp фракции 20/40 (рис. 5). Снижение проводимости и проницаемости моделей трещин ГРП составляет: для ЭСС-1 в 68 и 66 раз; для ЭСС-2 в 238 и 237 раз соответственно.

\section{ЗАКЛЮЧЕНИЕ}

Результаты комплекса проведенных фильтрационных экспериментов позволили исследовать и оценить блокирующие свойства коллоидных систем, представленных эмульсионными и эмульсионносуспензионными системами с содержанием твердых наноразмерных частиц до 1,5\% об. Определено, что фильтрация систем ЭСН и ЭСС в моделях сверхпроводимых трещин ГРП с проницаемостью от 397 Дарси при пропанте CarboProp фракции 20/40 для Тортасинского месторождения до 1365 Дарси при пропанте CarboProp фракции 16/20 для Абдуловского и Югома- шевского месторождений приводит к существенному снижению фильтрационных параметров пропантной упаковки по водному раствору хлорида калия. Так, снижение проводимости моделей трещин ГРП для пропанта фракции 16/20 составляет 23 раза для образца ЭСН-1 и 18 раз для образца ЭСН-2, а для пропанта фракции 20/40 66 раз для образца ЭСС-1 и 237 раз для образца ЭСС-2. Данные результаты свидетельствуют о потенциально высокой технологической эффективности применения разработанных систем ЭСН и ЭСС в таких процессах разработки месторождений как интенсификация добычи нефти, увеличение нефтеотдачи, строительство и подземный ремонт нефтяных и газовых скважин. В зависимости от цели применения систем, решаемых задач и пластовых условий оптимальная концентрация наночастиц для ЭСН может находиться в интервале от 0,5 до 1,0\% об., а для ЭСС в интервале от 0,5 до 1,5\% об. Однако оптимальные концентрации как твердой, так и жидких фаз данных систем должны быть уточнены по результатам опытно-промышленных испытаний и промышленного масштабирования новых систем.

\section{СПИСОК ЛИТЕРАТУРЫ}

1. Nguyen, D., Wang, D., Oladapo, A., Zhang, J., Sickorez, J., Butler, R., \& Mueller, B. (2014, April 12). Evaluation of Surfactants for Oil Recovery Potential in Shale Reservoirs. Society of Petroleum Engineers. doi:10.2118/169085-MS.

2. Alvarez, J. O., \& Schechter, D. S. (2016, April 11). Altering Wettability in Bakken Shale by Surfactant Additives and Potential of Improving Oil Recovery During Injection of Completion Fluids. Society of Petroleum Engineers. doi:10.2118/179688-MS.

3. Taheri, M., Bonto, M., Eftekhari, A. A., \& M. Nick, H. (2019, March 15). Towards Identifying the Mechanisms of the Modified-Salinity Waterflooding by a Novel Combination of Core flooding and Mathematical Modeling. Society of Petroleum Engineers. doi:10.2118/195110-MS.

4. Downs, J., \& Fleming, N. (2018, February 7). Evaluating Formation Damage Predictions Drawn from HPHT Core Flooding Tests on Brent Group Sandstone Reservoir Cores with Heavy Formate Drill-in Fluids: A Case Study from the Huldra Field. Society of Petroleum Engineers. doi:10.2118/189530-MS.

5. Al-Saedi, H.N., Al-Jaberi, S.K., Al-Bazzaz, W., \& Flori, R.E. (2019, October 21). Experimental Study of Flooding both Low Salinity Water and Foam in Sandstone Reservoirs Bearing Heavy Crude Oil. Society of Petroleum Engineers. doi:10.2118/198675MS.

6. Sergeev, V., Kim, I., Zeigman, J., \& Yakubov, R. (2018, November 12). Innovative Water-Blocking Agent Based on High Stable Emulsion with Nanoparticles for IOR Implementation. Society of Petroleum Engineers. doi:10.2118/192742-MS.

7. Sergeev V.V., Russkikh K.G., Zeigman Y.V., Yakubov R.N. Experimental research of the impact of filtration processes on the dispersity of emulsion systems with nanoparticles. Nanotehnologii v stroitel'stve = Nanotechnologies in Construction. 2019, Vol. 11, no. 1, pp. 31-41. DOI: 10.15828/2075-8545-2019-11-1-31-41.

8. Sergeev V.V., Zainullin I.I., Zeigman Y.V., Yakubov R.N. Research for the selective- ness of emulsion systems with $\mathrm{SiO}_{2}$ nanoparticles. Nanotehnologii v stroitel'stve $=$ Nanotechnologies in Construction. 2018, Vol. 10, no. 6, pp. 18-44. DOI: dx.doi. org/10.15828/2075-8545-2018-10-6-18-44.

9. Shah, S.Y., As Syukri, H., Wolf, K.-H., Pilus, R.M., \& Rossen, W.R. (2020, February 1). Foam Generation in Flow Across a Sharp Permeability Transition: Effect of Velocity and Fractional Flow. Society of Petroleum Engineers. doi:10.2118/195517-PA.

10. Коровин К.В., Печерин Т.Н. Опыт и перспективы применения химических технологий повышения нефтеотдачи на территории Ханты-Мансийского Автономного Округа - ЮГРЫ // Фундаментальные исследования. - 2016. № 12-5. - С. 993-997.

11. Крянев Д.Ю. Методы увеличения нефтеотдачи: опыт и перспективы применения / Крянев Д.Ю., Жданов С.А. // Нефтегазовая вертикаль. -2011. - № 5. 
12. Земцов Ю.В. Обзор физико-химических МУН, применяемых в Западной Сибири, и эффективности их использования в различных геолого-физических условиях / Земцов Ю.В., Баранов А.В., Гордеев А.О. // Нефть. Газ. Новации. 2015. - № 7. - C. 11-122.

13. Overview of the Russian oilfield services market - 2019. Deloitte CIS Research Center Moscow. 2019. 36 p.

14. Ключевые тенденции на рынке научно-исследовательских и проектных работ в нефтегазовой отрасли России 2014 Deloitte CIS Research Center Moscow. - 2014. - 16 p.

15. Zeigman Y.V., Mukhametshin V.Sh., Sergeev V.V., Kinzyabaev F.S. Experimental study of viscosity properties of emulsion system with $\mathrm{SiO}_{2}$ nanoparticles. Nanotehnologii v stroitel'stve = Nanotechnologies in Construction. 2017, Vol. 9, no. 2, pp. 16-38. DOI: dx.doi.org/10.15828/2075-8545-2017-9-2-16-38.

16. Zeigman Yu.V., Belenkova N.G., Sergeev V.V. Experimental research of stability of emulsion systems with $\mathrm{SIO}_{2}$ nanoparticles. Nanotehnologii v stroitel'stve $=$ Nanotechnologies in Construction. 2017, Vol. 9, no. 5, pp. 36-52. DOI: dx.doi. org/10.15828/20758545-2017-9-5-36-52.

17. Sergeev V.V., Belenkova N.G., Zeigman Yu.V., Mukhametshin V.Sh. Physical proper- ties of emulsion systems with $\mathrm{SiO}_{2}$ nanoparticles. Nanotehnologii v stroitel'stve $=$ Nanotechnologies in Construction. 2017, Vol. 9, no. 6, pp. 37-64. DOI: dx.doi. org/10.15828/2075-8545-2017-9-6-37-64.

18. V Sergeev, K Tanimoto, and M Abe. The Water-blocking Agent with Improved Properties for IOR Implementation. Conference Proceedings, IOR $2019-20^{\text {th }}$ European Symposium on Improved Oil Recovery, Apr. 2019, Volume 2019, p. 1-11. European Association of Geoscientists \& Engineers. Doi.org/10.3997/2214-4609.201900162.

19. Sergeev, V., Tanimoto, K., \& Abe, M. (2019, November 11). Innovative Emulsion-Suspension Systems Based on Nanoparticles for Drilling and Well Workover Operation. Society of Petroleum Engineers. doi:10.2118/197510-MS.

20. ГОСТ Р 51761-2013 (2014) Национальный стандарт российской федерации. Пропанты алюмосиликатные. Технические условия.

21. ГОСТ 8.417-2002 (2003) Межгосударственный стандарт. Государственная система обеспечения единства измерений. Единицы величин (введен в действие Постановлением Госстандарта РФ от 04.02.2003 № 38-ст).

22. ISO 13503-5:2006 (2006) Промышленность нефтяная и газовая. Растворы и материалы для вскрытия продуктивного пласта. Часть 5. Методики измерения долгосрочной удельной проводимости расклинивающих наполнителей.

\section{ИНФОРМАЦИЯ ОБ АВТОРАХ}

Сергеев Виталий Вячеславович, кандидат технических наук, директор по инновациям ООО «ВИ-ЭНЕРДЖИ», Фонд «Сколково, г. Москва, 121205, Россия, sergeev@vi-energy.ru

Шарапов Ринат Расихович, заведующий лабораторией геомеханических исследований, ООО «РН-БашНИПИнефть», г. Уфа, Республика Башкортостан, 450006, Россия, sharapovrr@bashneft.ru

Кудымов Алексей Юрьевич, начальник отдела геомеханических исследований горных пород ООО «ТННЦ», г. Тюмень, Тюменская область, 625048, Россия, aykudymov@tnnc.rosneft.ru

Зейгман Юрий Вениаминович, доктор технических наук, профессор, зав. каф. «Разработка и эксплуатация нефтяных и газонефтяных месторождений» ФГБОУ ВО «Уфимский государственный нефтяной технический университет», г. Уфа, Республика Башкортостан, 450062, Россия, jvzeigman@gmail.com

Мухаметшин Вячеслав Шарифуллович, доктор технических наук, профессор, директор филиала ФГБОУ ВО «Уфимский государственный нефтяной технический университет» В г. Октябрьский, г. Октябрьский, Республика Башкортостан, 452600, Россия, vsh@of.ugntu.ru

Статья поступила в редакцию: 11.03.2020.

Статья поступила в редакцию после рецензирования: 07.04.2020.

Статья принята к публикачии: 09.04.2020. 